\title{
Шляхи створення вузлів стикування систем термостатування ракет космічного призначення
}

\author{
С. О. Бігун ${ }^{1}$, М. С. Хорольський ${ }^{2}$ \\ ${ }^{1}$ Державне підприємство «Конструкторське бюро «Південне» імені М.К. Янгеля», \\ вул. Криворізька, 3, м. Дніпро, 49008, Україна, e-mail: sbigun58@gmail.com \\ 2 Дніпровський національний університет імені О. Гончара, \\ просп. Гагаріна, 72, м. Дніпро, 49000, Україна, e-mail: khomis@ outlook.com
}

\begin{abstract}
Задача з проектування вузлів стикування (BC) систем термостатування (CT) ракет космічного призначення (РКП) вперше виникла в Украӥні $і$ в ДП «КБ «Південне»», починаючи з розробки КРК «Циклон-4». До иього на аналогічних комплексах за дані пристрої відповідали підприємства Російської Федерації з кооперації. В прочесі створення вузлів стикування систем термостатування розробники вивчили доступний досвід зарубіжних фірм i зіткнулися із рядом труднощіів при розробиі власного виробу. У представленій статті висвітлено перелік таких проблемних питань та шляхи їх вирішення. Окрім того, викладені основні вимоги, шүо пред'являються до ВС з боку РКП і наземного комплексу. Вказані найбільш проблематичні з них з точки зору реалізації в конструкиії ВС. Це і мінімізація зусиль впливу на РКП в процесі від'єднання, $i$ компенсація просідань при заправиі РКП з одночасним збереженням з'єднання ВС, і наявність критичних зовнішніх чинників. В тому числі, таких як кліматичні умови, біологічні икідники та інші вимоги, щзо відносяться до надійності герметизачї, живучості, теплозахисних характеристик, надійності, довговічності, гарантійних зобов'язань та ін. На підставі иілого комплексу досліджень в статті запропоновано иляхи створення ВС СТ для РКП, які відповідають всім вимогам, щзо пред'являються. Слід зазначити універсальність, простоту $i$ надійність пропонованого рішення по створенню ВС СТ для використання в складі будь-яких відомих у світовій практиці ракетно-космічних комплексів.
\end{abstract}

Ключові слова: Системи термостатування; Вузли стикування; Ракети космічного призначення

(C) The Author(s) 2018. This article is an open access publication

This work is licensed under the Creative Commons Attribution 4.0 International License (CC BY) http://creativecommons.org/licenses/by/4.0/

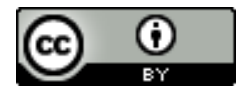

ONAFT

Open Access

\section{1. Вступ}

Створення наземного технологічного обладнання взагалі, і систем термостатування (СТ), зокрема, для запусків космічних ракет-носіїв за програмою «Циклон4» поставило на порядок денний цілий ряд нових задач, що потребують вирішення. Серед них вперше в Україні виникла і задача з розробки вузлів стикування (підключення) (ВС) СТ повітрям низького тиску зі своїми споживачами - головним блоком і «сухими» відсіками ракети-носія (РН). До цього на аналогічних комплексах за дані пристрої відповідали підприємства Російської Федерації з кооперації, або підприємства інших країн. ВС з'єднують технологічне обладнання наземної СТ і борт ракети. Вони є кінцевою ланкою системи на шляху проходження термостатуючого продукційного повітря. Тому ВС відносять до числа інтерфейсів космічного ракетного комплексу. Від їх нормальної роботи безпосередньо залежать якість, ефективність та надійність наземного технологічного устаткування, РН і космічного комплексу в цілому.

\section{2. Анализ інформаційних джерел і постановка проблеми}

В процесі створення ВС розробники вивчили доступний досвід зарубіжних фірм, що займаються подібним напрямом у техніці. Окрім того, виявили практич- ну відсутність інформації про них в публікаціях і зіткнулися із рядом труднощів при розробці власного виробу.

Аналіз умов підготовки до пуску і експлуатації, а також наявність можливих ситуацій при пусках ракет, включаючи аварійні, визначив безліч вимог до ВС СТ, в тому числі, і суперечливих, які належало виконати, дозволив сформулювати ці вимоги. Основні з них, на наш погляд, такі [1]:

1) герметичність та надійність;

2) багатократне приєднання до борту ракети і від'єднання від нього, при необхідності;

3) автоматичне від'єднання від ракети космічного призначення (РКП) при мінімальних зусиллях;

4) мінімальний силовий вплив на борт ракети в процесі подачі термостатуючого повітря і при від'єднанні від борту;

5) компенсація технологічних, монтажних і просадочних зсувів і похибок, зі збереженням при цьому зв'язків між ракетою і наземною СТ;

6) забезпечення геометрії з'єднань 3 урахуванням зовнішніх силових та інших впливів і заданої витрати повітря;

7) виключення можливих забруднень;

8) збереження цілісності і живучості в процесі впливу експлуатаційних факторів при дотриманні тривалих гарантійних зобов'язань;

9) низька теплопровідність і стійкість до біоло- 
гічних шкідників, хлоридів, сонячної радіації та інших факторів впливу;

10) невисока вартість у порівнянні із зарубіжними аналогами з метою забезпечення конкурентоспроможності на ринку пускових послуг.

Аналіз доступних зарубіжних аналогічних конструкцій показав, що вони побудовані або на основі зрізуваних одноразових металевих елементів, або на базі торових пневмопружинних вузлів.

Очевидно, перше виконання ВС має складний конструктивний склад із залученням спеціальної наземної системи відведення. На практиці буває так, що при спрацьовуванні системи відведення i, як наслідок, від'єднанні вузла стикування від борту, пуск РН за різних причин може бути відмінений або відкладений. В цьому випадку потрібний деякий час для заміни вузла, що спрацював, на новий із запасних частин. Друге виконання вимагає наявності на старті додаткового газобалонного обладнання для залучення пнемопружинного механізму вузла стикування і спеціально навченого персоналу для роботи з ним. Як видно, обидва варіанти досить затратні і складні.

Розглянувши доступні зарубіжні аналоги і перелічені вище вимоги, можна прийти до висновку про те, що вони можуть бути забезпечені застосуванням ВС на основі гумового матеріалу, оскільки гумі властива високоеластична деформація, низький модуль пружності при зміні форми виробу, і виконати всі зазначені вимоги, які знайшли своє відображення в технічному завданні ДП «Конструкторське бюро «Південне» імені М. К. Янгеля» $[2,3]$.

\section{3. Основна частина}

На підставі цілого комплексу теоретичних і практичних досліджень, а також певних розрахунків, було встановлено, що зазначені вимоги до ВС можуть бути виконані більш простою і в той же час досить надійною конструкцією. Така пропонується авторами (рисунок 1) із застосуванням комбінованого триєдиного гу-мового рукава (далі - «рукава»), забезпеченого метале-вим вузлом фіксації-розфіксаціі (ВФР), який установлюється на ущільнювальному фланці.

Як видно з рисунка 1, вузол стикування містить комбінований гумовий рукав 1 , який своїм ущільнювальним знімним фланцем 2 приєднується до горловини термостатування (далі - «горловина») 3 одного боку, а циліндричною незнімною частиною 4 приєднується до трубопроводу 5 системи термостатування за допомогою двох хомутів 6 з черв'ячним механізмом з іншого боку. Гофрована частина 7 рукава забезпечує його приєднання до горловини ракети 3 під різними кутами, як по виcoті, так і в окружному напрямі, не змінюючи прохідного перетину (заданої витрати повітря), а також дозволяє компенсувати монтажно-технологічні та просадочні зсуви і похибки, не порушуючи при цьому зв'язків між ракетою і наземною СТ.

3 метою забезпечення надійної герметизації в процесі подачі продукційного повітря, що супроводжується наявністю вібрацій і коливань певної частоти, на ущільнювальний фланець 2 рукава по зовнішньому діаметру у спеціальну канавку 8 установлюється вузол фіксації-розфіксаціі 9 бандажного типу, забезпечуючи задану радіальну деформацію стінки ущільнювального фланця 2.

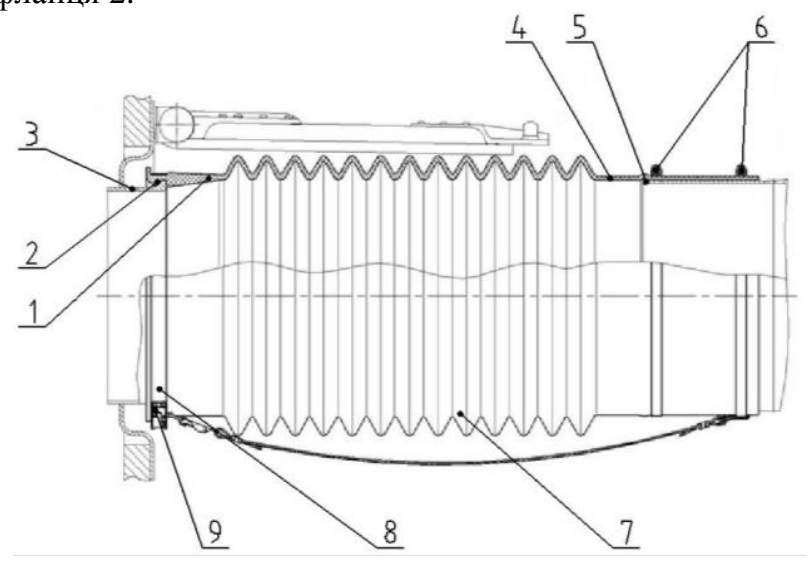

Рисунок 1 - Схема вузла стикування системи термостатування: 1 - гумовий рукав; 2 - ущільнюва-льний фланец; 3 - горловина ракети; 4 - циліндрична частина рукава, 5- трубопровід СТ, 6-хомути для приєднання рукава до трубопроводу СТ, 7 - гофрована частина рукава; 8 - канавка в рукаві для розміщення вузла фіксації-розфіксаиіi; 9 - вузол фіксації-розфіксаиіi

Figure 1 - The scheme of the attachment assembly for thermal conditioning system (TCS): 1 - rubber sleeve; 2 seal flange; 3 - rocket neck; 4 - cylindrical section of the sleeve; 5 -pipeline of TCS; 6 -clamps the sleeve to the pipeline of TCS; 7 - corrugated section of the sleeve; 8 groove in sleeve for locating the fixation-de-fixing unit; 9 fixation-de-fixing unit

Загальний вигляд рукава, що складається 3 трьох частин, зображено на рисунку 2 разом з заглушками [2].

Заглушки 4, 6 забезпечують захист внутрішньої порожнини рукава від попадання забруднень. Перед монтажем вони знімаються.

У випадку відміни пуску рукав по ущільнювальному фланцю 1 від'єднується, і на нього знову установлюється заглушка 6 для виключення попадання у трубопровід СТ можливих забруднень.

Показана на рисунку 3 конструкція ВФР, що складається 3 бандажа 1, із закріпленими на ньому стопорним і фіксуючим механізмами, і троса 2 з карабіном для кріплення до чеки стопорного механізму, забезпечує необхідну надійність герметизації, зручність в експлуатації і відповідає основним вимогам, що пред'являються. Окрім того, конструкція даного вузла дозволяє реалізувати всі відомі на даний час способи роз'єднання ВС з горловинами ракети в процесі передстартової підготовки і пуску. У цьому значенні створений ВФР є універсальним і унікальним пристроєм.

Перед стартом РКП штатне відокремлення рукава від горловини проводиться так: стріла установника, відхиляючись від борту ракети, розтягує гофровану частину рукава, який, подовжуючись внаслідок наявності гофр, натягує провисаючий трос 2 до спрацьовування чеки стопорного механізму бандажа 1 ВФР (див. рисунок 3). Звільнений за допомогою стопорного і фіксуючого механізмів від обтиснення бандажем рукав по ущільнювальному фланцю розтягується у діаметральному напрямі під дією внутрішнього надлишкового тиску 
термостатуючого повітря, що рухається, а також через відхилення стріли установника, що тягне за трос ВФР, плавно, $з$ мінімальним зусиллям сходить 3 горловини ракети. Аналогічно, відділення рукава від горловини термостатування може відбутися і при русі ракети під час старту або одночасно з ходом ракети і відхиленням стріли установника.

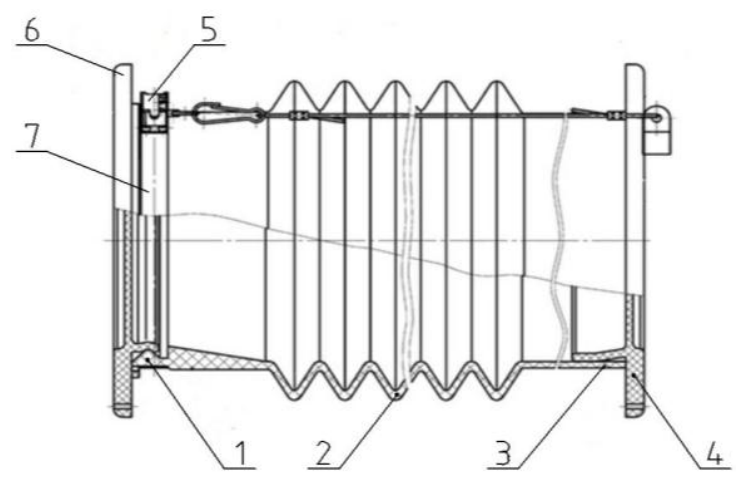

Рисунок 2 - Загальний вигляд рукава вузла стикування:1 - ущільнювальний фланець рукава (знімна частина); 2 - гофрована частина рукава (компенсуюча), 3 циліндрична частина рукава (незнімна); 4 - заглушка циліндричної частини, 5 - вузол фіксаџї-розфіксаціі; 6 - заглушка ущільнювального фланця; 7 - канавка niд $B \Phi P$

Figure 2 - The general form of the sleeve of the attachment assembly: 1 - seal flange of the sleeve (removable section), 2 - corrugated section of the sleeve (compensating), 3 cylindrical section of the sleeve (non-removable), 4 - cap of the cylindrical section, 5 - fixation-de-fixing unit; 6 - cap of the seal flange; 7 - groove for locating the fixation-defixing unit.
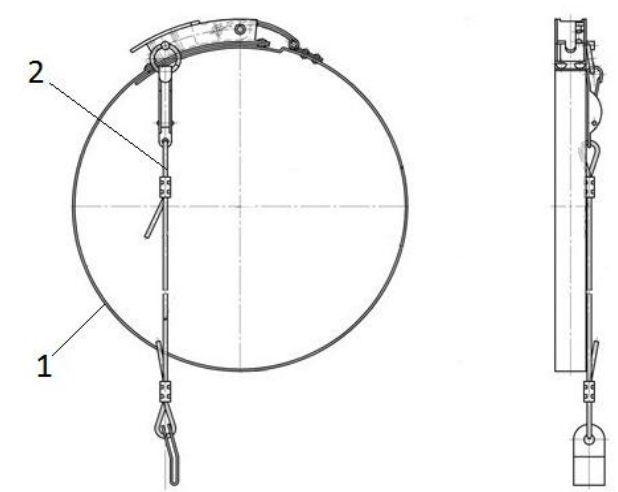

Рисунок 3 - Загальний вигляд вузла фіксаиії-розфіксаиїі: 1 -хомут; 2 - трос

Figure 3 - The general form of the fixation-de-fixing unit: 1 - clamp, 2-hawser

При відміні пуску ракети рукав вручну знімається 3 горловини термостатування 3 подальшою установкою штатної заглушки у горизонтальному положенні установника. При необхідності рукав можна повністю демонтувати у цьому ж положенні установника.

Зазначені ВС за участю авторів були виготовлені і випробувані на спеціальному стенді [4] в умовах, близьких до експлуатаційних за розширеною програ- мою, що враховує всі вказані вимоги до ВС. Отримано позитивні результати.

Таким чином, авторами пропонується технічне рішення зі стикування наземного технологічного устаткування і борту ракети для СТ.

Слід зазначити простоту і надійність пропонованого рішення по створенню ВС СТ для застосування у складі будь-яких відомих космічних ракетних комплексів. При цьому, всі елементи вузла стикування виконані в Україні на Державному підприємстві «Український науково-дослідний конструкторсько-технологічний інститут еластомерних матеріалів і виробів» - головною науковою організації України по еластомерним матеріалів і виробам на їх основі.

\section{4. Висновки}

На основі проведених теоретичних і практичних досліджень можна зробити наступні висновки:

1. Виконано аналіз сучасних технічних рішень ВС СТ РКП, виявлено їх позитивні і негативні сторони;

2. Вперше в Україні сформульовано основні вимоги до ВС СТ наземних комплексів для забезпечення підготовки та пуску РКП, і при цьому визначені проблемні питання;

3. Запропоновано наукові основи проектування ВС СТ для комплексного рішення проблемних питань, включаючи можливі критичні ситуації;

4. Розроблено, виготовлено і випробувано в заводських умовах при статичних робочих тисках повітря ВС СТ з позитивними результатами;

5. Запропоновано конструктивні технічні рішеньня для інтерфейсів наземного технологічного обладнання;

6. Продемонстрована можливість розробки і виготовлення в Україні ВС СТ у складі будь-яких відомих в світовій практиці космічних ракетних комплексів.

\section{Література}

1. Бигун С. А. Типы и конструктивные особенности узлов стыковки систем термостатирования головных блоков и отсеков ракет-носителей космических аппаратов [Текст] / С. А. Бигун, Ю. А. Еланский, М. С. Хорольский // Космическая техника. Ракетное вооружение: науч.-техн. сб. - Д.: ГП «КБ «Южное»», 2013. Вып. 1 (103), - 123 с - С. 65-68.

2. Большой справочник резинщика [Текст]. В 2 ч. Ч. 1. Каучуки и ингредиенты / под ред. С. В. Резниченко, Ю. Л. Морозова. - М.: ООО «Издательский центр ««Техинформ» МАИ», 2012.-744 с.; ил.

3. Большой справочник резинщика [Текст]. В 2 ч. Ч. 2. Резины и резинотехнические изделия. / под ред. С. В. Резниченко, Ю. Л. Морозова. - М.: ООО «Издательский центр ««Техинформ» МАИ», 2012.- 648 с.; ил.

4. Экспериментальные исследования результатов отработки узлов стыковки системы термостатирования РКН «Циклон-4» /С. А. Бигун, М. С. Хорольский, А. И. Скоков, С. В. Каплун // Космическая техника. Ракетное вооружение: науч.-техн. сб. - Д.: ГП «КБ «Южное»», 2016. - Вып. 2 (112) - С. 43-51.

Отримана в редакції 01.11.2017, прийнята до друку 07.02.2018 


\title{
Routes in designing attachment assemblies for thermal conditioning systems of integrated launch vehicles
}

\author{
S. Bigun ${ }^{1}$, M. Khorolskyi ${ }^{2}$ \\ ${ }^{1}$ Yuzhnoie State Design Office, 3 Krivorozhskaya St, Dnepr, 49008, Ukraine \\ e-mail: sbigun58@gmail.com \\ ${ }^{2}$ Oles Honchar Dnipro National University, 72, Gagarin Avn, Dnepr, 49000, Ukraine \\ e-mail: khomis@outlook.com
}

The first time Yuzhnoye State Design Office (and actually Ukraine) faced the problem of designing assemblies for attaching thermal conditioning systems (TCS) to integrated launch vehicles (ILV) was when it started developing the Cyclone-4 expendable launch system. Before that, the attachment assemblies (AA) for the launch vehicles similar to Cyclone-4 were bought from outside companies under cooperation agreements. Before the developers got down to work on AA for TCS, they gained a deeper insight into similar projects successfully completed by foreign engineers. Yet, they faced a number of design challenges in the course of AA development. The report highlights the main problems encountered while designing the attachment assemblies. Beyond that, it presents the key requirements to the attachment assemblies for their compatibility with ILV and the ground complex, with a special focus on the requirements which are most difficult to meet. They include reduction of forces acting on ILV when it is separated from the ground complex at different angles; compensation for a smaller distance between ILV and the ground complex resulting from loading of fuel into ILV, while preserving the operability of the attachment assemblies; resistance to such external influences as climatic conditions and pests, as well as requirements for air tightness, durability, reliability, warranty, heat-shielding performance, etc. The report suggests the design of the attachment assembly satisfying all the requirements. It is also important to note that the proposed design of AA for TCS can be used for any type of known orbital launch vehicles.

Keywords: Thermal conditioning systems; Attachment assemblies; Integrated launch vehicles

\section{References}

1. Bigun S. A., Elanskii Yu. A., Khorolskyi, M. S. (2013).

Tipy i konstruktyvnye osobennosti uzlov stykovki system termostatirovaniia holovnykh blokov i otsekov raketnositelei kosmicheskikh apparatov. Kosmicheskaia tekhnika. Raketnoe vooruzhenie: nauch.-tekhn. sb., D.: GP «KB «Yuzhnoe»», Vyp. 1 (103),P. 65-68. (in Russian)

2. Bolshoi spravochnik rezinshchika. V 2 ch. Ch. 1. Kauchuki i inhredienty (2012), M.: OOO «Izdatelskii tsentr ««Tekhinform» MAI», 744. (in Russian)
3. Bolshoi spravochnik rezinshchika. V 2 ch. Ch. 2. Reziny i rezinotekhnicheskie izdeliia. (2012), M.: OOO «Izdatelskii tsentr ««Tekhinform»MAI», 648. (in Russian)

4. Bigun S. A., Khorolskyi M. S., Skokov A. I., Kaplun S. V. (2016) Eksperimentalnie issledovaniia rezultatov otrabotki uzlov stykovki sistemy termostatirovaniia RKN «Tsyklon-4». Kosmicheskaia tekhnika. Raketnoe vooruzhenie: nauch.-tekhn. sb., D.: GP «KB «Yuzhnoe»», Vyp. 2 (112), 43-51. (in Russian) 